\title{
ALEGORIA DO DUELO E OS CONFLITOS ESCOLARES
}

\author{
Paulo Meksenas
}

\begin{abstract}
RESUMO: O objetivo deste artigo é analisar o conto "Duelo", de João Guimarães Rosa, e localizar os elementos que caracterizam alguns aspectos da sociabilidade brasileira. Fazendo uso de analogias críticas, quando tratamos um texto literário também como uma alegoria, é possível indicar como determinado conflito escolar decorre de interação social na qual o "eu" se faz pela busca da "aniquilação" física ou simbólica do "outro", definido sempre como um inimigo a ser superado. Uma sociabilidade compreendida por meio da alegoria do duelo indica os riscos do esfacelamento do tecido social que estamos presenciando no Brasil.
\end{abstract}

Palavras-chave: Alegoria do duelo. Padrões de sociabilidade. Conflitos escolares.

\section{THE ALLEGORY OF DUEL AND SCHOOL CONFLICTS}

ABSTRACT: Analyzing the short story Duel, by João Guimarães Rosa, and finding elements that characterize a standard of Brazilian sociability are the main objectives of this paper. By means of critical analogies, which include treating a literary text as an allegory, we can show how certain school conflicts emerge: they are caused by social interactions in which egos develop by searching the physical or symbolic "annihilation" of the other, always defined as an enemy to be overcome. A sociability understood through the allegory of duel indicates the risk of destruction of the social tissue that we have been witnessing in Brazil.

Key words: Allegory of duel. Standard of sociability. School conflicts.

Doutor em Educação e professor adjunto da Universidade Federal de Santa Catarina (UFSC).E-mail: meksenas@terra.com.br 


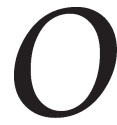
diálogo que se estabelece nas fronteiras das ciências humanas com a literatura e destas com a educação tem sido fértil, ao ponto de indicar novas possibilidades para reflexôes comprometidas com a intervenção politicamente orientada na vida social. Talvez Rousseau seja um dos maiores exemplos do esforço da superação de dicotomias que se poderiam dar entre tais campos do conhecimento e da expressão humana. Julia ou a nova Heloisa, publicado em 1761, e Emílio ou da Educação, em 1762, mesmo ano em que também publicou o Contrato social, entre uma múltipla e variada obra, mostrou que é possível o colóquio crítico da filosofia com a literatura e destas com a educação.

Comentando modalidades presentes nos estudos de tipo sociológico em literatura, Antonio Cândido afirmou que, em todas essas diferentes perspectivas, se encontra "o deslocamento de interesse da obra para os elementos sociais que formam a sua matéria, para as circunstâncias que influíram na sua elaboração, ou para a sua função na sociedade" (2000, p. 12). Estes modos de operar com a literatura são, entretanto, secundários, "se não forem considerados segundo a função que exercem na economia interna da obra" (idem, ibid.). Nessa contradição, entre a obra que espelha o conceito e a obra como expressão, é que se localiza o desafio a que nos propomos. Em outros termos, essas poucas e iniciais considerações corroboram a intenção deste artigo em abordar aspectos da dinâmica dos conflitos escolares a partir da leitura de um conto de João Guimarães Rosa.

Temos a sensatez de admitir que, se muito foi escrito sobre este literato e sua obra, não é o caso de repetir tais análises e sim de partir da alegoria presente no "Duelo", que integra o conjunto dos contos em Sagarana, para encontrar ali alguns dos elementos característicos da sociabilidade brasileira e relacioná-los a contextos empíricos da educação escolar. Para atingir o objetivo proposto é necessário, primeiramente, indicar o lugar da alegoria nesta reflexão. Uma alegoria é a substituição de um contexto por outro, figurado, que transmite um significado diverso em adição ao primeiro significado literal. Peça central na retórica, a alegoria é utilizada como um recurso didático e a sua apresentação é tanto verbal como escrita, pois, segundo Hansen (2006, p. 7 e 8), "a alegoria (grego allós = outro; agourein = falar) diz $\mathrm{B}$ para significar A (...) e o verbo grego állegorein, por exemplo, tanto significa falar 
alegoricamente' quanto 'interpretar alegoricamente”. Desse modo, é perceptível que a alegoria atravessa o tempo como um recurso de expressão e assume a forma da narrativa, que serve de instrumento e exemplo à reflexão acerca da realidade social. Além de expressão literária, é uma expressão filosófica. Basta lembrarmos a "Alegoria da caverna", presente na República de Platão. No contexto deste artigo, o objetivo é compreender como o processo interativo entre docentes e discentes assume a forma do conflito. Um conflito em que as relações do eu com o outro se fazem mediante a freqüente possibilidade de aniquilação física ou simbólica desse outro. A alegoria do duelo é, nesse sentido, ilustrativa de aspectos das interações sociais que ocorrem com projeções sobre o campo da educação escolar.

Iniciar pensando, junto com Guimarães Rosa, nas características que fazem parte de um padrão de sociabilidade nacional e brasileira pautada por meio da alegoria do duelo. Destacar aspectos dessa sociabilidade; os seus sujeitos-personagens e as características/trama de um enredo, em suma, partir de belo e oportuno conto deste literato universal e articulá-lo com situações empíricas a envolver conflitos escolares. Finalizar com alguns aspectos da interação docentes-discentes e postos para o debate. Eis a proposta!

\section{Guimarães Rosa e a alegoria do duelo}

Guimarães Rosa, em carta endereçada a João Condé, comentou que a redação do conto "Duelo", que integra o corpo literário de Sagarana, foi uma "história meditada e 'vivida', durante um mês, para ser escrita em uma semana, aproximadamente” (2006, p. 394). Este conto pode ser lido como alegoria de algumas qualidades que tipificam as interações sociais no Brasil, ocorrendo sob a contradição do moderno com o tradicional.

O conto começa pela descrição dos aspectos que formam a personalidade do protagonista Turíbio Todo e apresenta-o como um capiau. Em vários momentos, o nome de Turíbio é substituído pelo gênero do qual faz parte: o capiau é personagem do sertão - o brasileiro no cotidiano - e faz a síntese que resultou de nossa situação colonial: os personagens são capiaus porque estabelecem relações sociais que estão dentro e fora do capitalismo europeu, simultaneamente, ou, como quer 
Guimarães Rosa, es-te-den-tro e este fora. O que temos por tradição é a cultura que veio com o colonizador e remodelada em meio aos colonizados: índio; negro e branco pobre a gerirem artefatos e técnicas, fabricando uma cultura nacional e popular. Assim, a nossa tradição se fez barroca, absolutista, agrária e paternalista. A ela, lentamente, somou-se o moderno que é tecnológico, liberal, urbano e impessoal. No amálgama da tradição com a modernidade é que a personalidade do protagonista do "Duelo" se compôs:

Turíbio Todo, nascido à beira do Borrachudo, era seleiro de profissão, tinha pêlos compridos nas narinas, e chorava sem fazer caretas; palavra por palavra: papudo, vagabundo, vingativo e mau. Mas no começo dessa estória, ele estava com a razão. (2006, p. 154)

Estava com a razão não só porque o episódio em questão e a envolvê-lo lhe dava motivos à vingança. Bem mais do que isso, estava com a razão significa que, apesar de herdeiro da tradição, Turíbio era moderno no seu modo de pensar e no situar-se frente ao mundo. Em outras palavras, era um homem que não agia apenas por costume arraigado; por crença ou por afetividade, mas, sobretudo, agia "por expectativas quanto ao comportamento de outras pessoas, utilizando essas expectativas como 'condiçôes' ou 'meios' para alcançar fins próprios, ponderados e perseguidos racionalmente" (Weber, 1991, p. 15) e, assim, era uma pessoa que tinha na razão o seu guia. Turíbio Todo é, no plano geral, personagem síntese de culturas feitas em trópicos modernos e assombradas pela tradição. No plano contextual, Guimarães Rosa o define como:

(...) bastante misantropo, e dali querido ser seleiro, para poder trabalhar em casa e ser menos visto. Ora, com a estrada-de-ferro, e, mais tarde, o advento das duas estradas de automóvel rarearam as encomendas de arreios e cangalhas, e Turíbio Todo caiu por força na vadiação. (2006, p. 154)

Turíbio Todo era um capiau e "saibamos todos, os capiaus gostam muito das relaçôes de causa e efeito, leviana e dogmaticamente inferidas" (idem, ibid.). E assim atribuiu à causa de um mau dia em sua vida, quando saíra para pescar, a perder iscas e a machucar-se, o efeito do azar de, ao voltar mais cedo para casa e ver a sua mulher, Dona Silvana, nos braços de Cassiano Gomes. E antes mesmo que agisse por afetividade; antes que os sentimentos aflorassem, falou a razão e 
Turíbio não fez nada, "e não fez, porque o outro era Cassiano Gomes, ex-anspeçada do $1^{\circ}$ pelotão da $2^{a}$ companhia do $5^{\circ}$ Batalhão de Infantaria da Força pública” (idem, p. 155).

Quando tudo levava à resolução passional, Turíbio Todo agiu com prudência, resignou-se, racionalizou e depois calculou a sua ação na forma de uma estratégia, pois, "como o bom, o legítimo capiau, quanto maior é a raiva tanto melhor e com mais calma raciocina (...) respirava fundo e sua cabeça trabalhava com gosto, compondo urdidos de vingança" (idem, ibid.). Convêm indicar que estratégia é um conceito sociológico que indica uma determinada qualidade da ação social frente aos processos de racionalização, presentes no mundo moderno. Segundo Max Weber, ainda citando Economia e sociedade (1991), priorizar a estratégia consiste em conquistar um domínio nas ações sociais para a realização dos interesses do sujeito que age, calculando suas ações de forma a adequar os meios aos fins propostos. Aqui, os meios não possuem um valor intrínseco, ou seja, não podem ser avaliados em si mesmos, pois no âmbito de uma estratégia nunca podemos julgar se os meios para atingir um determinado fim são bons ou maus, apenas se funcionam ou não, pois são medidos à luz de sua eficácia. No conto "Duelo", de Guimarães Rosa, o cálculo e a estratégia estão a serviço da vingança e, aos personagens envolvidos, não importa apenas a qualidade justa ou não da ação, mas se a ação é ou não funcional e como pode vir a sê-lo. O conto evolui e a trama se arma:

Bem, quinta-feira de manhã, Turíbio Todo teve por terminados os preparativos, e foi tocaiar a casa de Cassiano Gomes. Viu-o à janela, dando as costas para a rua. Turíbio não era mau atirador; baleou o outro bem na nuca. E correu em casa, onde o cavalo o esperava na estaca, arreado, almoçado e descansadão.

Nem por sonhos pensou em exterminar a esposa (Dona Silvana tinha grandes olhos, de cabra tonta), porque era um cavalheiro, incapaz de covardia de maltratar uma senhora, e porque basta, de sobra, o sangue de uma criatura, para lavar, enxaguar e enxugar a honra mais exigente.

Agora tinha de cair no mundo e passar algum tempo longe, e tudo estaria muito bem, conseqüente e certo, limpamente realizado, igualzinho a outros casos locais. (2006, p. 156)

Turíbio calculara a ação como um moderno, mas o seu cálculo não se fez totalmente moderno porque o seu raciocínio estava preso a uma linearidade que é inexistente nos acontecimentos modernos. 
Falhou como uma pessoa moderna por inferir a relação de causa e efeito de modo leviano e dogmático, isto é, não considerou o acaso e o imponderado, que também tipificam as relações modernas. Assim, dentro de sua lógica linear imaginava passar algum tempo longe, e tudo estaria muito bem, igualzinho a outros casos locais. Mas não foi isso o aconteceu:

Houve um pequeno engano, um contratempo de última hora, que veio pôr dois bons sujeitos, pacatíssimos e pacíficos, num jogo dos demônios, numa comprida complicação: Turíbio Todo, iludido por uma grande parecença e alvejando um adversário por detrás, eliminara não o Cassiano Gomes, mas sim o Levindo Gomes, irmão daquele, o qual não era metralhador, nem ex-militar e nem nada, e que, por sinal, detestava mexida com mulher dos outros. Turíbio Todo soube do erro, ao subir no estribo. (Idem, p. 157)

O conto em análise revelou que um contexto imprevisível conduziu a interação de indivíduos, pois um contratempo de última hora - o alvejar a pessoa errada - veio pôr dois bons sujeitos, pacatíssimos e pacíficos, num jogo dos demônios. Assim, a trama se iniciou por um súbito a colocar personagem contra personagem numa comprida complicação. Uma perseguição teve lugar por meses a fio e a vingança virou um jogo. ${ }^{1} \mathrm{O}$ jogo é uma atividade que pressupõe a (1) idéia referente ao jogador. $\mathrm{O}$ sujeito da ação que considera sua possibilidade de interferir ativamente na atividade ou resignar-se passivamente diante do seu desenvolvimento. Com isso, podemos dizer que o jogador lida com pares antagônicos: acaso-cálculo; destino-talento; fatalidade-esforço. A tensão destes pares ocorre de modo que, sempre a cada primeiro termo, revela a impotência do sujeito-que-joga e, sempre ao segundo termo, a necessidade de sua atuação excelente. Nos primeiros termos dos pares em questão, a ação do sujeito é desnecessária ou inútil; nos segundos, é determinante do resultado, o que nos leva à (2) idéia de obtenção de resultados, definida quando de seu desfecho, considerando uma de duas possibilidades expressas pelos estados antagônicos de sucesso-fracasso, derrota-vitória, bom-mau e onde ambos os termos, um excluindo o outro, têm lugar. Entre Turíbio Todo e Cassiano Gomes o jogo se fez, essa foi uma das características do duelo:

Cassiano pensou, fumou, imaginou, trotou, cismou, e, já a duas léguas do arraial, na grande estrada do norte, os seus cálculos acharam conclusão: Turíbio Todo tinha uns parentes na Piedade do Bagre, ou ali por menos 
longe (...). Para lá batera, direitinho, ainda assustado por conta do malfeito. (Rosa, 2006, p. 157)

E Cassiano Gomes tinha acertado, em parte Turíbio Todo viera mesmo para Piedade do Bagre (...) mas bastara-lhe um dia de repouso, para compreender que estava num fundo-de-saco, pois aquele lugarejo era a boca do sertão (...). Mas não voltou como onça na ânsia da morte: baldeou e fez que vinha e não veio, e fez como o raposão. Obliquou a rota para nor-nordeste. (Idem, ibid., p. 158)

E, desse jeito, visto que Turíbio Todo talvez fosse mais ladino e arisco, durante dois meses as informações foram vasqueiras e vagas, e nunca se soube bem por onde então eles andaram ou por quais lugares foi que deixaram de andar. (Idem, ibid., p. 160)

$\mathrm{E}$ assim deu-se o jogo, integrante desse duelo. O que vimos acima foi misto de acaso-cálculo; destino-talento; fatalidade-esforço e onde, no inicio do conto, Turíbio Todo ficou com os primeiros termos destes pares e Cassiano Gomes com os segundos. A estratégia tinha por princípio a geografia - o espaço - e, portanto, o apostar em caminhos que levassem o inimigo a imaginar atalhos errados. Mas a estratégia também ia além dos domínios do espaço e deu-se por comunicação distorcida: Turíbio Todo "teve a audácia de passar no arraial, porque estava com saudades da mulher, Dona Silvana - aquela mesma que tinha belos olhos grandes, de cabra tonta -, com quem ficou uma noite" (idem, ibid., p. 162). Disse à mulher que estava apenas cansando Cassiano, na espera que o outro - o inimigo - tivesse um ataque cardíaco, pois sabia que não ia bem do coração. Deveras, a tal notícia espalhou-se e chegou aos ouvidos de Cassiano, mas, "como Turíbio Todo falara a verdade, para o outro pensar que fosse trapaça, assim se deu que Cassiano tinha errado mais uma vez. E continuou o longo duelo, e com isso já durava cinco ou cinco meses e meio a correria, monótona e sem desfecho" (idem, ibid., p. 161). Vemos aqui como a comunicação assumiu a racionalidade do jogo proposto: Turíbio Todo, ao falar a verdade, espera que ela, a verdade, seja lida/interpretada como uma mentira. A comunicação torna-se um elemento integrante do ato de duelar. $\mathrm{Ou}$, o duelo também se faz por comunicação distorcida.

Neste ponto, uma outra e breve reflexão: o "Duelo", como escrito por Guimarães Rosa, não se resolve rapidamente como qualquer outro duelo, ao contrário, é lento, vagaroso e surdo, dura meses e assume a 
forma do jogo racional. É um duelo pouco passional, pouco tradicional. No conto em análise,

(...) a técnica utilizada no duelo serve para demonstrar a perspicácia de cada um (...). Na verdade essa técnica é contraditória na medida em que não ocasiona o encontro entre ambos. A maestria é ressaltada pelo narrador para ser negada na narrativa. Chegam a caminhar paralelamente, um em relação ao outro, sem se cruzarem. A probabilidade de se encontrarem é enorme, mas não é o que acontece. (Santos, 2007, p. 111)

E assim decorre o duelo em que os desafiantes nunca se põem frente a frente, um com o outro e de modo direto, visível ou transparente. Ao contrário, a relação social de ambos se dá por mediaçôes; contando com a ajuda de terceiros; com as informaçōes vasqueiras e vagas; de modo indireto e pouco visível. Pensar no estabelecimento de interações sociais que ocorrem pela mediação de outros sujeitos para além dos imediatamente envolvidos ou, em outros termos, pensar em relaçôes sociais feitas por mediações pessoais, porém, distorcidas e mal intencionadas é o que dá o matiz à sociabilidade posta no conto. Aqui o duelo deixa de ser moderno e volta a ser tradicional. Mas, afinal, o que é o "Duelo": um retrato do tradicional ou do moderno? Com o Brasil em mente, temos que é um retrato dos dois, simultaneamente, e Guimarães Rosa o ensina, vê estes pólos como contradição e não como simples oposição. No Brasil, as relaçôes sociais são pré-modernas, além de hodiernas. Nossa sociabilidade é pautada pelos valores agrários e urbanos; está entre a arte e a técnica; entre a retórica e a ciência, enfim, entre o recorrente e o inovador:

E Cassiano Gomes, por ter apenas vinte e oito anos e, pois, ser estrategista mais fino, vinha pula-pula, ora em recuos estúrdios, ora em bizarras demoras de espera, sempre, sempre bordando espirais em torno do eixo da estrada-mãe. Mas Turíbio Todo, sendo mais velho, tinha mais força de ser melhor tático, e vinha vai-não-vai, em marcha quebrada, como um vôo de borboleta, ou melhor, de falena, porque ele também se fizera noctâmbulo; e levava além disso estupenda vantagem, traquejado no terreno, que lhe era palma das mãos. (Rosa, 2006, p. 160)

O mais velho, seleiro, vivido no campo duela com o mais novo, que é militar, formado na cidade. Vemos aqui o tradicional a duelar com o moderno, mas é um duelo diferente, indireto, feito por mediações, 
lento, surdo, crescente, aonde um busca aniquilar o outro e sempre almejando os despojos do possível perdedor. E como essa alegoria da sociabilidade brasileira evoluiu no conto?

Por momentos, o leitor tem a impressão de que o duelo se esvai, do mesmo modo que o coração de Cassiano Gomes. Sentenciado pelo boticário a pouco tempo de vida, Cassiano decide vender tudo o que possuía e passar na cidade onde vivia sua mãe, por fim, caçar Turíbio Todo na cidade de São Paulo, que para lá o seu desafeto tinha partido, segundo as mais recentes informaçōes. Mas o problema cardíaco foi implacável e o deixou a meio caminho, num vilarejo chamado Mosquito, "pois foi lá que Cassiano Gomes teve o seu desarranjo, com insuficiência mitral em franca descompensação. Desceram-no do cavalo e deramlhe hospitalidade. E ele foi para um jirau, com a barriga de hidrópico e a respiração difícil de um cachorro veadeiro que volta da caça" (2006, p. 174). E percebendo o seu fim ainda com uma vingança por cumprir, Cassiano compreendeu que apenas um fiel compadre poderia dar uma resolução ao seu caso. Nesse momento da narrativa entra em cena um novo personagem, Timpim Vinte-e-Um, o capiau que, ao receber toda a ajuda financeira de Cassiano para salvar a vida do filho doente, promete-lhe cumprir o ato derradeiro. E assim disse o capiau:

- Deus há de lhe dar o pago, seu Cassiano Gomes! Eu sim que não posso, por causa que não tenho préstimo nenhum... O menino é porque foi batizado na horinha em que nasceu, senão o senhor tinha de ser o padrinho!... Mas, assim, se o senhor deixar, eu fico sendo seu compadre e o senhor fica sendo o meu compadre mais-de-todos, que eu de tantas caridades nunca hei de me esquecer!...

(...)

Depois o moribundo respondeu:

- Esse dinheiro fica todo pra você, meu compadre Vinte e Um...

Aí, tomou uma cara feliz, falou na mãe, apertou nos dedos a medalhinha de Nossa Senhora, morreu e foi para o Céu.

(...)

Turíbio Todo soube da boa notícia, por uma carta da mulher, que, agora carinhosa, o invocara para o lar. Ele tinha ganho já bons cobres, e a carta acabou de o convencer: comprou mala, comprou presentes, pôs um lenço verde no pescoço, para disfarçar o papo; calçou botas vermelhas, de lustre e veio. (Rosa, 2006, p. 179) 
Na metade do caminho de volta, Turíbio Todo recebe a companhia de um capiau que viaja na mesma direção que a sua; estabeleceram uma conversa superficial e, quando passavam com os cavalos por um lugar ermo, o capiau se apresentou como Timpim Vinte-e-Um, dizendo que estava ali para honrar o seu compromisso com o compadre Cassiano Gomes. A vítima implorou pela vida, ofereceu dinheiro, ofereceu argumentos e, quando percebeu de que nada faria o outro capiau mudar de idéia,

(...) curvou de banda e puxou o revólver, e foi um golpe de rédeas e outro de esporas fazendo o cavalo se empinar.

Mas a garrucha não negou fogo. Turíbio Todo pendeu e se afundou da sela, com uma bala na cara esquerda e outra na testa. $\mathrm{O}$ cavalo correu; o pé do defunto se soltou do estribo. O corpo prancheou, pronou, e ficou estatelado.

Então, o caguinxo Timpim Vinte-e-Um fez também o em-nome-do-padre, e abriu os joelhos, esporeando. E o cavalinho pampa se meteu, de galope, por um trilho entre os itapicurus e os canudos-de-pito, fugindo do estradão. (Rosa, 2006, p. 185)

E assim termina o conto! Temos, no "Duelo" de João Guimarães Rosa, um desenho, entre outros possíveis, da alegoria que destaca aspectos da sociabilidade nos trópicos modernos. É viável afirmar que as interações sociais no Brasil ocorrem pela oposição do eu com o outro, à medida que o primeiro busca superar o segundo e vice-versa. Como na imagem de um duelo - porém, atípico, porque racional e se arrastando pelo tempo, vagarosamente, sem nunca tornar efetiva a presença dos opositores -, o estabelecimento do desafio toma a forma de jogo; um jogo que, ao pressupor a vitória de um e a derrota do outro, pressupóe, na verdade, a morte de ambos enquanto um eu e um outro. E foi assim que Turíbio Todo interagiu com Cassiano Gomes e ambos com Dona Silvana, destacando que esta última emergiu como uma mera ferramenta na mão dos principais protagonistas. Dona Silvana não era uma finalidade em si mesma, apenas um meio. Um meio para cada um dos opositores lutarem e jogarem por seus próprios objetivos. Timpim Vinte-e-Um também aparece como ferramenta/meio que serve a um propósito alheio ao seu. Este último exemplifica a sociabilidade que se dá pela troca de presentes ou favores. Assim, o presente e o favor tomam o lugar das relações contratuais em nossa sociedade, do mesmo modo que a vingança tomou o lugar da justiça. 
O duelo marca interações sociais desafiadoras, lentas, capazes de aniquilar pelo desejo de vingança, tão típico entre nós, e a nos pautar entre os opostos que se dão no amor e no ódio; na compaixão e na frieza; na arte e na técnica; no presente e no castigo; na obrigação e no favor; na sina e no inesperado; no destino e na história. A sociabilidade brasileira é feita por estes pares opostos, a combinarem-se de modo que o moderno existe para fazer cumprir com o tradicional. Uma sociabilidade pautada pelo duelo faz com que nem o eu e nem o outro ganhem. Na verdade, os desafiantes se aniquilam mutuamente. O duelo tem um propósito antagônico: é uma sociabilidade que desfaz a própria sociabilidade. E como aspectos dessa sociabilidade podem ser localizados na educação e em que medida pode elucidar a dinâmica dos conflitos escolares? Entre tantas outras possíveis, uma resposta a essa indagação é discutida a seguir, a partir de caso empírico.

\section{Conflitos escolares: a sociabilidade pelo duelo}

O que se segue é uma reflexão a partir de alguns fatos registrados na grande imprensa escrita e que, na interlocução com as interpretaçóes que fizemos acerca do conto "Duelo", de Guimarães Rosa, permitirá destacar aspectos que dão matiz à sociabilidade na educação escolar. E tomamos a educação escolar como mais um exemplo dessa sociabilidade dada pelo duelo e que ocorre nos diversificados âmbitos sociais. Não é o caso, portanto, de realizar uma análise pormenorizada de fatos por meio das notícias que se tem deles; menos ainda em estudá-los na perspectiva da compreensão do discurso do jornalismo impresso. O que se almeja nesta segunda parte do artigo é a inter-relação entre literatura e análise social, que toma os fatos empíricos como mediadores da reflexão que está em processo.

Os fatos que registramos aqui se passaram na pequena cidade de Taiúva, no estado de São Paulo, distante 363 quilômetros da capital. Os seus poucos mais de cinco mil habitantes presenciaram um caso aparentemente inusitado. Era janeiro de 2003 e a imprensa local e nacional estampou em manchete: "Armado com um revólver calibre 38 e munido de 105 balas, o ex-aluno de escola estadual, Luiz, ${ }^{2} 18$, invadiu o pátio da instituição, em Taiúva, atirou 14 vezes contra alunos, professores e funcionários, ferindo oito pessoas. Luiz se matou em seguida” (Correio Brasiliense, 28 jan. 2003). Chamado de 'Vinagre' pelos 
colegas de sala, dadas as suas faces rosadas, Luiz nasceu na própria cidade de Taiúva, era obeso e vinha de uma família de lavradores de baixa classe média. Luiz guardava na sua casa uma arma calibre 22 e um poema de John Lydon, pai do movimento punk e um dos ídolos do estudante. Segundo relatou o mesmo jornal, constam os seguintes versos no poema: "dentro de sua cabeça, chumbo calibre 22".

O fato abalou aos moradores da pacata Taiúva. "É uma coisa em que ainda não conseguimos acreditar", disse Edson, comandante da Polícia Militar da cidade. Ainda, segundo apurou o jornal Folha de S. Paulo (29 jan. 2003), "nem a direção da escola, polícia ou familiares sabem o que motivou o crime, já que Freitas, que estava desempregado, era uma pessoa calma, aparentemente não usava drogas e não se envolvia com brigas". Assim, "nunca esperávamos uma coisa dessas, muito menos vindo dele", disse a prima de Luiz, Sonia.

Funcionários da escola estadual confirmaram que Luiz estudou na instituição desde o primeiro ano do ensino fundamental e completou o ensino médio em 2003, sempre com boas notas. Segundo a Fotha de S. Paulo: "Ele nunca deu problemas, era educado, sempre andou bem vestido. Era muito meu amigo", disse a diretora Maria de Lourdes. Há, entretanto, outra versão e que contradiz a dominante. O estudante Rogério relatou, em entrevista ao mesmo jornal (29 jan. 2003), que ele [o ex-aluno] olhou para mim e disse: "Você não". E saiu, indicando que Luiz sabia em quem iria atirar, isto é, parece que houve premeditação, planejamento e escolha dos alvos humanos.

Analisando os relatos dos jornais que cobriram o caso, é possível perceber contradições nas falas dos depoentes. Houve uma tendência à normalização do assassino-suicida, que destacou qualidades como: não usava drogas, era pacato, sempre agiu dentro dos padrões sociais etc. Essa versão aparece nos depoimentos de alguns dos familiares de Luiz, mas o que chama a atenção é o fato de muitos discentes, professores e mesmo a direção do estabelecimento escolar reforçam a tese do "ato inexplicável", que Luiz era normal e num rompante comete uma atrocidade. É claro que o inexplicável precisou ser explicado e aí a tese médica teve o seu lugar. Ao mesmo tempo em que alguns depoentes destacaram a existência de uma pessoa de boa índole, isso não o impediu de ter um surto. Com essa versão é possível inocentar a qualidade das relações sociais que se estabelecem no interior da escola e, por isso, ela 
foi difundida, sobretudo pelos agentes escolares, que possuíam a nítida propensão à defesa da instituição.

Em relato dado à Folha de S. Paulo, o professor de psicologia da violência, Sérgio, comentou o comportamento de Luiz, considerando a possibilidade de um surto e não um caso de loucura e concluiu: "geralmente são pessoas que têm um histórico de humilhação ou inferiorização. A escola é o lugar em que mais ocorre esse tipo de coisa, porque os colegas não perdoam qualquer problema que a pessoa tenha”. Ora, mesmo em se tratando de um possível surto, o citado professor deu indicações de que o fato poderia relacionar-se a uma história anterior. Defendendo essa outra versão, a de premeditação e planejamento da ação em função de provável vingança, uma ex-colega disse à imprensa que Luiz chegou a sair chorando da sala de aula por ser chamado de "gordo" e "vinagrão". Cinco outros discentes, que conviveram com o rapaz, confirmaram que "ele disse que iria matar a classe toda, mas nunca ninguém acreditou”. Ainda, segundo o mesmo jornal, à época dos acontecimentos foi afirmado que "a polícia suspeita que Luiz atirou deliberadamente em pelo menos duas pessoas: a professora Glória (ferida de raspão na perna) e o aluno Arnaldo, 17, o Dunga" (Folha de $S$. Paulo, 29 jan. 2003).

Os fatos indicam que, além da interpretação do caso pelo 'inexplicável' e, portanto, por meio da idéia do ato irracional, havia outra versão, a de um gesto premeditado e relacionado à execução de um plano e, portanto, racional. Aqui é possível parodiar Guimarães Rosa e afirmar que Luiz estava com a razão, no sentido de possuí-la como guia das suas ações. É com esta segunda versão do caso que devemos lidar, se o compreendemos como um duelo. Após anos sofrendo ataques ofensivos, à surdina e cotidianos, por isso mesmo ataques "invisíveis", Luiz se decide por uma ação racional, pois "como o bom, o legítimo capiau, quanto maior é a raiva tanto melhor e com mais calma raciocina (...) respirava fundo e sua cabeça trabalhava com gosto, compondo urdidos de vingança" (Rosa, 2006, p. 155). Aqui está a alegoria do duelo a caracterizar os aspectos da sociabilidade em questão. Luiz duelou com a escola e com parcela de sujeitos ali imersos. E como todo duelo à brasileira, produziu um jogo de vingança, construído lentamente e durante anos, com o objetivo de aniquilar todos aqueles que humilhavam a sua honra. Assim, deu-se o jogo e o que vimos neste caso 
empírico foi um misto de acaso-cálculo, destino-talento, fatalidade-esforço. É claro que nem tudo ocorre conforme o planejado e "houve um pequeno engano, um contratempo de última hora" (idem, ibid., p. 157) e, por volta das $15 \mathrm{~h}$, quando Luiz saltou o muro lateral do colégio, com mais de dois metros de altura, esqueceu-se de que,

Naquele horário, intervalos das aulas, cerca de 50 alunos do ensino médio estavam no pátio conversando. Sem dizer uma palavra, o ex-aluno começou a atirar para todos os lados, aleatoriamente. Feriu cinco pessoas. Uma delas, Antonia, de 17 anos, gravemente. Ao entrar no prédio da escola, ele recarregou a arma e recomeçaram os disparos. Mais duas pessoas foram atingidas: a professora Glória, 44, e o aluno Arnaldo - que era a vítima em estado mais grave até o início da noite. De volta à parte externa do prédio, Luiz seguiu em direção à zeladoria, onde atirou contra o caseiro João, 55. Lá, ainda segundo familiares e diretoria, o ex-aluno apontou a arma contra o peito de MC, mulher do zelador, mas desistiu de atirar ao ser convencido por ela. Depois se matou. "Ela disse: 'Eu não, pelo amor de Deus'. Aí, ele encostou a arma no (próprio) ouvido e atirou", contou a prima. (Correio Brasiliense, 28 jan. 2003)

No conto de Guimarães Rosa, o duelo aconteceu entre um seleiro e um ex-militar. No caso de Taiúva (SP), foi entre um aluno e uma instituição: a escola. Daí a dificuldade em localizar os sujeitos a serem o objeto da vingança porque, para Luiz, poderia ser qualquer discente, qualquer docente e qualquer funcionário, dentre o grupo em que tinha os seus desafetos. A dificuldade em localizar os sujeitos da vingança reforça a idéia de que o duelante estava, na verdade, num jogo mortal com a instituição. $\mathrm{O}$ caso em questão não é atípico, como seria previsível imaginar. Segundo pesquisa realizada pela UNESCO em 2002 e citada por Abramovay (2002), a violência está presente em 83,4\% das escolas brasileiras. Frente a este quadro, um estudo anterior já advertia que,

(...) embora os resultados sejam bem fragmentários, é possível considerar que os anos 1990 apontam mudanças no padrão da violência observada nas escolas, atingindo não só os atos de vandalismo, que continuam a ocorrer, mas as práticas de agressões interpessoais, sobretudo entre o público estudantil. Dentre estas últimas, as agressōes verbais e ameaças são as mais freqüentes. (...) as incivilidades sinalizariam, também, um conjunto de insatisfações manifestadas pelos alunos diante de sua experiência escolar e, ao mesmo tempo, as dificuldades da unidade escolar em criar 
possibilidades para que tais condutas assumam a forma de um conflito capaz de ser gerido no âmbito da convivência democrática. (Spósito, 2001, p. 94 e 100)

Nota-se que a questão central recai sobre a qualidade das interações sociais que se estabelecem entre os sujeitos inseridos nas instituições escolares. O que Spósito (2002) indica diz respeito aos conflitos escolares tenderem para uma resolução autoritária, em que a ausência do diálogo parece acentuar o caráter de disputa racional, onde um busca aniquilar o outro, definido como inimigo e igual a um duelo.

Aos fatos já mencionados somam-se outros. No site oficial do Sindicato dos Professores do Ensino Oficial do Estado de São Paulo (APEOESP: www.apeoesp.org.br; acesso em: 11 nov. 2007), os dados de uma pesquisa feita com 684 docentes revelaram a percepção dos professores em relação à violência no ambiente escolar. Nota-se que a violência atinge a todos, desde professores, discentes, passando por funcionários até chegar à comunidade. De acordo com as informações publicadas no site indicado, $74 \%$ dos entrevistados disseram conhecer casos de professores ameaçados dentro da escola e 68\% afirmaram conhecer situações em que alunos sofreram ameaças. ${ }^{3}$

As pesquisas que se fazem acerca da ocorrência de açôes escolares violentas parecem indicar que o foco de tais açôes não é o furto, mas tentativas de atingir a instituiçãao e pessoas ligadas a ela. Ou seja, os discentes no Brasil duelam com outros discentes, com professores e também com funcionários das escolas, à medida que um se relaciona com o outro na perspectiva de defini-lo como inimigo. O que vemos é um padrão de sociabilidade em que o eu busca aniquilar o outro, seja física ou simbolicamente, e ambos correm o risco de se aniquilarem mutuamente. Outro caso, agora relatado no jornal $O$ Globo, ocorrido em julho de 2005 em escola da cidade do Rio de Janeiro, aponta que

Um aluno, de 13 anos, estudante de Escola Municipal, no Parque União, diz que foi espancado pelo professor de Geografia, identificado como Eduardo, dentro da sala de aula. No momento em que eu sai da sala de aula, uma garota bateu na porta. Eu estava próximo e o professor pensou que tivesse sido eu a bater na porta. Ele correu atrás de mim e começou a me bater. O professor me pegou no ombro e me deu um soco do olho. Ele botou a mão na minha cara, enquanto ficava me batendo. Depois, ele pegou meu material, amassou, rasgou tudo e jogou dentro da lata de lixo, contou o aluno. 
O que restou do material escolar está dentro da mochila: muitas folhas rasgadas e amassadas. (Disponível em: <http://rjtv.globo.com/RJTV/ 0,19125,VRV0-3114-100625-2005071-341,00.html>. Acesso em: 25 nov. 2007)

Numericamente, os fatos não são poucos. Considerando os acontecimentos que não terminam em atos extremos da aniquilação física, a dedução a que se chega é pela existência de muitos mais casos, a ponto de integrarem a rotina escolar, isto é, de fazerem parte da sociabilidade ali presente. Neste artigo, e apesar de enfatizarmos os casos extremos, não é descartada a possibilidade de que o duelo assuma a feição da subjetividade: um duelo lento, surdo, duradouro e que pode conduzir à morte simbólica de sujeitos que se envolvem em alguns contextos escolares. Esta outra dimensão do duelo é rotineira: o professor que, por exemplo, aplica provas com o intuito de punir o discente por um mal feito passado e este se utiliza da "cola" para defender-se; depois, desestabiliza o humor presente em aula, como vingança ao docente que lhe atribuiu a nota zero na prova. Professores com atitudes que levam os discentes a desacreditarem em suas próprias capacidades de aprendizado. Os discentes, por sua vez, "sabotam" a aula para atingir o professor. É um duelo sem fim. Um jogo com estratégias e premeditação; calculado, enfim, racional, com suas "relações de causa e efeito, leviana e dogmaticamente inferidas” (Rosa 2006, p. 154). Um duelo que não ocorre apenas nos pólos docente e discente, mas se afirma em múltiplos outros pólos: professor e professor; discente e discente; funcionário e funcionário; funcionário e professor; funcionário e discente; ainda destes com os pais; parentes e a "comunidade", que envolve o espaço preenchido pela instituição. A sociabilidade pelo duelo está conduzindo ao espírito do bellum omninum contra omne. ${ }^{4}$

Em uma entrevista dada à revista Mundo Jovem, também reproduzida no Observatório Ibero-Americano de Violência nas Escolas, Miriam Abramovay, socióloga e secretária executiva deste mesmo Observatório, afirmou que

Temos um lado, onde todos são vítimas. O professor é vítima porque recebe xingamentos, agressões, muita ameaça. Alguns professores até abandonaram a escola porque recebiam ameaças contra sua própria família. Encontramos também danos ao patrimônio do professor, riscar carros, furar pneus etc. Então, fala-se que o clima escolar, hoje, é muito ruim. 
Encontramos também alunos que são xingados, desrespeitados, alunos que sofrem agressão verbal e outros que sofrem violência simbólica. Ouvimos comentários de alunos onde foi reforçada a sua baixa auto-estima: "sai daqui, você nunca vai aprender", "você nunca vai ser nada", "pode deixar a escola, você vai ser pedreiro", "nem pense em fazer vestibular um dia, você nunca vai entrar na universidade" etc.

Quem é o culpado? Na verdade, todos são culpados e todos são vítimas. Todos estão numa situação tão complicada que nem os professores conseguem ensinar direito e nem os alunos conseguem aprender. E, assim, fica muito difícil dar continuidade e pensar numa qualidade de ensino. (Disponível em: <http://www.violenciasnasescolas.org.br/news_outubro01.php>. Acesso em: 27 nov. 2007)

O problema indica que os conflitos escolares, que se dão sob a ótica do duelo, não decorrem do âmbito em que estão inseridos, isto é, a escola não os "inventou". A sociabilidade pelo duelo é anterior à escola e faz parte da nossa herança colonial, cujas normas econômicas e políticas deram-se por meio do matar, dominar, ocupar, explorar e retirar, em suma, do aniquilar a terra e o ser humano ali presente. Desse modo, a sociabilidade do duelo faz parte de contexto maior, sendo possível a sua generalização como um importante aspecto da interatividade nacional, que se afirmou através da nossa história. $O$ duelo está no Congresso, assim como está na universidade e basta colecionarmos casos empíricos para comprovar. O duelo está nas empresas, nos sindicatos, partidos, agremiaçôes religiosas e culturais, enfim, o duelo está na sociedade. Daí essa sociabilidade não se restringir às instituições escolares. Se as tomamos como paradigma empírico deste artigo, não significa, por outro lado, que os conflitos escolares sejam oriundos de uma sociabilidade escolar, mas apenas que essa sociabilidade reproduz uma outra e de caráter mais geral. Todos os espaços sociais organizados aparecem como palco do duelo, em que o eu interage com o outro para superá-lo e, como no conto de Guimarães Rosa, ambos podem ser aniquilados.

Outros exemplos podem ser construídos para além da educação escolar. A título de destaque, notamos que a sociabilidade do duelo está presente e se faz quase imperceptível quando um administrador de empresas disputa uma ascensão funcional com um colega no interior de uma empresa; ou quando um dirigente sindical propóe uma greve apenas com o intuito de disputar hegemonia em seu território político; mesmo, um duelo pode se estabelecer na disputa de cargos nas universidades. 
O que almejamos destacar com estas questóes é a existência de um modo de interação social que põe em risco a existência de outros padrôes de sociabilidade, ou seja, é como se a sociabilidade pelo duelo pusesse em xeque a própria existência da sociabilidade. Corremos o sério risco de estarmos presenciando o desmanchar das relações sociais; o esfacelamento da sociedade. Algo deve ser feito, e prestar mais atenção no outro do que no eu talvez seja um passo importante para questionar a sociabilidade pautada pelo duelo.

Recebido em fevereiro de 2008 e aprovado em outubro de 2008.

\section{Notas}

1. Os conceitos de jogo e jogador, presentes neste estudo, têm como referência o trabalho de Meksenas (2003).

2. Todos os nomes aqui citados, apesar de aparecerem na imprensa na forma verídica, neste artigo foram substituídos por nomes fictícios. Tal atitude deve-se à intenção do autor em não expor tais nomes publicamente, mais do que já o foram. Além disso, porque os nomes fictícios não alteram a lógica da exposição e nem ferem com os objetivos propostos.

3. Disponível em: <http://www.apeoesp.org.br/especiais/violencia_escola.html>. Acesso em: 11 nov. 2007.

4. A guerra de todos contra todos.

\section{Referências}

ABRAMOVAY, M. Os tempos mudaram... E a escola? ; entrevista concedida ao Observatório Ibero-Americano de Violência nas Escolas, Brasília, DF, 31 out 1996. Disponível em: <http://www.violenciasnasescolas.org.br/ news_outubro01.php>. Acesso em: 27 nov. 2007.

ABRAMOVAY, M. et al. Escola e violência. Brasília, DF: UNESCO, 2002.

ALUNO acusa professor. O Globo, Rio de Janeiro, 1 jul. 2005. Disponível em: <http://rjtv.globo.com/RJTV/0,19125,VRV0-3114-1006252005071-341,00.html>. Acesso em: 25 nov. 2007.

CÂNDIDO, A. Literatura e sociedade. São Paulo: T.A. Queiroz; Publifolha, 2000.

HANSEN, J.A. Alegoria: construção e interpretação da metáfora. São Paulo: Hedra; Campinas: UNICAMP, 2006. 
JOVEM invade escola, fere oito e se suicida. Correio Brasiliense, Brasília, DF, 28 jan. 2003, p. 12.

MACHADO, N.J. A alegoria em matemática. Estudos Avançados, São Paulo, v. 5, n. 13, dez. 1991.

MEKSENAS, E. Uma leitura do poema: o jogo de Charles Baudelaire. Teresópolis: [s.n.], 2003. (mimeo.)

PAGNAN, R. Segundo a polícia, atirador de Taiúva escolheu alvos. Folha de São Paulo, São Paulo, 29 jan. 2003, p. 7.

ROSA, J.G. Sagarana. Ed. comemorativa. Rio de Janeiro: Nova Fronteira, 2006.

SANTOS, R.C. Veredas de Sagarana: linguagem, memória e verdade. 2007. 125f. Dissertação (Mestrado) - Programa de Pós-Graduação em Ciência da Literatura, Universidade Federal do Rio de Janeiro, Rio de Janeiro.

SPÓSITO, M.P. Um breve balanço da pesquisa sobre violência escolar no Brasil. Estudos Avançados, São Paulo, v. 27, n.1, p. 87-103, jan./jun. 2001.

WEBER, M. Economia e sociedade. Brasília, DF: UNB, 1991. 